\title{
To TPP or Not to TPP: That is Still the Question
}

\author{
Roja Subhasree Neppalli ${ }^{1}$, Richard J. Hunter, Jr. ${ }^{2 *}$ \\ ${ }^{I}$ MBA Candidate \\ ${ }^{2}$ Professor of Legal Studies and Economics, Stillman School of Business, Seton Hall University
}

*Corresponding Author: Richard J. Hunter, Jr, Professor of Legal Studies and Economics, Stillman School of Business, Seton Hall University

\begin{abstract}
This article is a discussion of the Trans-Pacific Partnership, better known as the TPP. It traces the origins and purposes of the agreement and delineates the important provisions of the TPP relating to tariffs, services, foreign investment, digital commerce, and intellectual property. The article focuses on the controversial Investor-State Dispute Settlement Mechanism and offers both positive and negative perspectives. The article concludes with commentary on the future course for the TPP, including its relevance to the growing importance and influence of China in the region.
\end{abstract}

Keywords: Trans Pacific Partnership; Tariff and Non-Tariff Barriers; Dispute Mechanism

\section{INTRODUCTION}

On January 23, 2017, the third day of his presidency, President Donald Trump signed an executive order withdrawing the United States from the Trans Pacific Partnership (TPP) (Presidential Memorandum, 2017; see also Mui, 2017; McBride, 2018). In so-doing, the President stated that it was his intention to deal directly with individual countries on a "one-on-one (or bilateral) basis in negotiating future trade deals" in order to "create fair and economically beneficial trade deals that serve their [the American worker] interest." [Appendix I-Presidential Statement]

The TPP, a multi-lateral trade agreement between Australia, Brunei, Canada, Chile, Japan, Malaysia, Mexico, New Zealand, Peru, Singapore, Vietnam, and United States, was signed on February 4, 2016 (see Lazo \& Fiedler, 2017). The purpose of the TPP, expressed in the Preamble, was to: “...[promote] economic integration to liberalize trade and investment, bring economic growth and social benefits, create new opportunities for workers and businesses, contribute to raising living standards, benefit consumers, reduce poverty and promote sustainable growth." [Appendix II - Text of the TPP] McBride (2018) has noted that the TPP was designed to guaranty higher living standards and assure that participating countries would gain access to new markets.

Even though President Obama had been a strong supporter of TPP, both of the presidential candidates in 2016, Democratic nominee Hillary Clinton and Republican nominee Donald J. Trump, announced their opposition to the TPP. However, Secretary Clinton's opposition was unexpected. In 2011, Secretary Clinton had claimed the "TPP sets the gold standard in trade agreements to open free, transparent, fair trade, the kind of environment that has the rule of law and a level playing field" (Carroll, 2015) and argued that with American leadership, the TPP would advance broader Asian integration efforts in support regional institutions like Asia-Pacific Economic Cooperation (APEC) (see Harvey, 2017). Under pressure from rival Senator Bernie Sanders and major elements of the American labor movement, still stinging from their disappointment with NAFTA, now candidate Secretary Clinton had reversed her earlier position (Berger, 2015).

After the withdrawal of the United States, the eleven remaining TPP countries agreed in May 2017 to revive the agreement (Jegarajah, Dale \& Shaffer, 2017). In March of 2018, these nations negotiated a new trade agreement called the Comprehensive and Progressive Agreement for Trans-Pacific Partnership (CPTPP), which incorporated many of the most important provisions of the TPP (Ming, 2018) — but without the participation of the United States. 


\section{ORIGINS OF THE TPP}

The TPP had its genesis as an expansion of the Trans-Pacific Strategic Economic Partnership Agreement (TPSEP or P4), originally signed by Brunei, Chile, New Zealand, and Singapore in 2005 (Ministry of Foreign Affairs \& Trade (New Zealand), 2005; GAO, 2010). In 2008, Australia, Canada, Japan, Malaysia, Mexico, Peru, the United States, and Vietnam joined the negotiations for a broader agreement, bringing the negotiating countries to twelve (Elms, 2017).

The original TPSEP agreement had affirmed the members' "commitment to encourage the accession to this Agreement by other economies" (Ministry of Foreign Affairs and Trade (New Zealand), 2005). The TPSEP was designed as a comprehensive agreement, affecting trade in goods, rules of origin, trade remedies, sanitary and phytosanitary measures, technical barriers to trade, trade in services, intellectual property issues, government procurement, and competition policy. The parties resolved to:

- "Strengthen the special links of friendship and cooperation among them;

- Enlarge the framework of relations among the parties through liberalising trade and investment and encouraging further and deeper cooperation to create a strategic partnership within the AsiaPacific region;

- Contribute to the harmonious development and expansion of world trade and provide a catalyst for broader cooperation at international forums;

- Create an expanded and secure market for their goods and services in their territories;

- Avoid distortions in their reciprocal trade;

- Ensure a predictable commercial framework for business planning and investment" (Ministry of Foreign Affairs and Trade (New Zealand), 2005).

Among other provisions, the TPSEP called for a 90 percent reduction of all tariffs between member countries by 1 January 2006, and a reduction of all tariffs to zero by the year 2015 .

In addition to providing for measures to lower both non-tariff and tariff barriers to trade (Hunter \& Lozada, 2010; Kaul, 2017) such as export tariff barriers, import tariff barriers, transit tariff barriers, quotas, subsidies, product and testing standards, embargoes, local content requirements, administrative delays, and currency controls (Sumner, Smith, \& Rosson, 2001), the original agreement had also established a highly controversial investor-state dispute settlement (ISDS) mechanism.

The U.S. International Trade Commission (ITC) (2016) found that the final agreement would, if ratified, lead to net positive economic outcomes for all signatories - but most especially for the United States. The ITC (2016, p. 22) noted:

"By year 15 (2032), U.S. annual real income would be $\$ 57.3$ billion ( 0.23 percent $)$ higher than the baseline projections, real GDP would be $\$ 42.7$ billion ( 0.15 percent) higher, and unemployment would be 0.07 percent higher (128,000 full-time equivalents). U.S. exports and imports would be $\$ 27.2$ billion (1.0 percent) and $\$ 48.9$ billion (1.1 percent) higher, respectfully, relative to baseline projections. U.S. exports to new FTA partners would grow by $\$ 34.6$ billion (18.7 percent); U.S. imports from those countries would grow by $\$ 23.4$ billion (10.4 percent)."

However, an "unorthodox model" suggested by two Tufts University economists argued that the agreement would adversely affect the signatories. According to the Global Development and Environment Institute at Tufts University, the TPP would actually reduce jobs in the United States by half a million (and 75,000 Japanese jobs, 58,000 Canadian jobs, and 5,000 jobs in New Zealand) and increase income inequality. Capaldo and Izurieta (2016a; 2016b) indicated that the United States would see a reduction in its manufacturing sector, but any losses would be offset by an increase in the agriculture and service sectors.

In terms of any potential geo-political impact (Green \& Goodman, 2015), some observers argued that the TPP was designed to reduce the signatory nations' dependence on China and bring the signatories closer to the positions of the United States (Naughton, Kroeber, De Jonquires, \& Webster, 2015). Perlez (2015) noted that the TPP was "seen as a counterweight to China's efforts to expand its influence not just in trade but in other areas, including in its island-building in the disputed South 
China Sea and the establishment of a new regional development bank to compete with Western-led institutions." Chow (2017, p. 370) stated that "China's exclusion from the TPP negotiations was no accident, but instead was a deliberate play by the U.S. to limit China's global trade influence. The U.S. did not want China's input on the terms of the TPP as is; rather, the U.S. wanted to dictate the terms of the TPP on its own, with the cooperation of the other compliant TPP members."

\subsection{TPP Provisions}

The TPP would have cut or significantly lowered over 18,000 tariffs. For example, tariffs on all U.S. manufactured goods and almost all U.S. farm products would be eliminated completely, with most eliminated immediately (Tupy, 2018). According to the non-partisan Congressional Research Service, TPP "would be the largest U.S. FTA [Free Trade Agreement] by trade flows ( $\$ 905$ billion in U.S. goods and services exports and $\$ 980$ billion in imports in 2014)" (Fergusson, McMinimy, \& Williams, 2016; generally, DeFilippo \& Powers, 2016). Granville (2016) reported that the signatories represented roughly $40 \%$ of global GDP (nearly $\$ 28$ trillion), and one-third of the volume of world trade.

What are some of the specifics of the TPP?

- TPP lowered tariffs on a wide range of manufactured goods, automotive and agricultural commodities such as meat, dairy, and grains. The estimated reduction for TPP members would be almost $98 \%$.

- Cross border restrictions on services (generally George, 2013; Bohn \& Brakman, 2018) were removed, and new rules were added to protect businesses offering services from host country discrimination or "special preferences" (generally, Guisinger, 2017). These include retail, communications, entertainment, and financial services.

- Markets will be open for foreign investment (FDI) among the TPP members and rules were added to protect investors from unfair treatment by eliminating so-called "Golden Share" arrangements as they existed throughout the region (Pezard, 1995; Che-Ahmad \& Mustafa, 2017). The controversial Investor State Dispute Settlement (ISDS) provision (described below) was included, which would allow investors to sue government using international arbitration panels on the basis of any alleged "unfair investment practices" (Quick, 2015) occurring within their borders.

- The TPP was the first regional trade agreement which included comprehensive rules on digital commerce (Mitchell \& Mishra, 2018), ensuring the free flow of information across borders and mandated consumer privacy protection rules.

- At the insistence of the United States, TPP incorporated extensive provisions relating to intellectual property (IP) protections (Cheng, 2006), including patent enforcement, extended copyright terms, and protections for technology and trade secrets. The TPP was also designed to protect new prescription drugs, which includes a class of medications called biologics (Wong, 2017) - a policy largely advanced by United States. For example, copyright protection would be granted for the life of the author plus 70 years and the agreement required signatories to establish criminal penalties for violations of copyright protections as well (Braga, 2017).

Other significant provisions included enhanced labor and environment standards, provisions related to child labor, and government transparency. The TPP would have streamlined regulatory requirements, making it easier for small businesses to engage in cross-border trading (McBride, 2018).

In addition to its significant tariff reductions and enhanced protections across a wide span of investment issues, the agreement mandated expedited customs procedures for express shipments and prohibited customs duties from being applied to electronic transmissions (generally, Peterson, 2017). The TPP also required additional privacy, security, and consumer protections for online transactions and encouraged the publication of online customs forms which might have particularly beneficial to small businesses (Gerwin, 2015).

In deciding to withdraw from the agreement, President Trump argued that the TPP was an unfair deal for United States. The President claimed that the TPP would accelerate the outsourcing of American manufacturing jobs (critics in Japan made the same claims) to under-developed and developing countries with low labor costs such as Viet Nam, and would exacerbate our already burgeoning trade deficit, which had reached $\$ 502.3$ billion in 2016 . 
Durden (2017) described the trade situation in the United States as follows: "Eports were \$2,209.4 billion in 2016, down 51.7 billion from 2015. Imports were $\$ 2,711.7$ billion in 2016, down $\$ 49.9$ billion from 2015. The 2016 increase in the goods and services deficit reflected a decrease in the goods deficit of $\$ 12.5$ billion or 1.6 percent to $\$ 750.1$ billion and a decrease in the services surplus of $\$ 14.4$ billion or 5.5 percent to $\$ 247.8$ billion. As a percentage of U.S. gross domestic product, the goods and services deficit was 2.7 percent in 2016, down from 2.8 percent in 2015."

While not all agreed that the TPP was a "flawed agreement" (Calmes, 2016), critics stated that the TPP failed to address the issue of currency manipulation by China (Chow, 2017) and other signatory nations (Klein, 2015; Contractor, 2016). Chow (2017, p. 295) notes that "Anti-China critics argue that the People's Republic of China (PRC or China) engages in a long-standing and intentional pattern of currency manipulation that artificially devalues the Chinese currency, the Renminbi, versus the USD."

President Trump stated that he would prefer to negotiate bilateral "deals" rather than multilateral arrangements (Presidential Memorandum, 2017; Taylor, 2018). Many of the supporters of the President slammed the TPP as a "secretive deal" which favored big business and the interests of other countries at the expense of exporting American jobs (WikiLeaks, 2015), intensifying a "race to the bottom" among signatory nations in their efforts to attract foreign investment (Granville, 2017). Questions were also raised regarding the significant "health risks" posed by the agreement (Martin, 2015) Labonte, Schram, \& Ruckert, 2016).

\section{THE ISDS}

One of the more controversial provisions of the TPP was the Investor-State Dispute Settlement Mechanism or ISDS (Chapter 9), which grants investors the right to sue foreign governments for treaty violations (generally, Otero \& Garcia-Bolivar, 2011). While the ISDS cannot overturn local laws (unlike the World Trade Organization) which violate the agreement, Provost and Kennard (2015) report that monetary damages can be awarded to investors who can successfully prove a violation of specific treaty provision (Davison, 2015).

From the American point of view, the ISDS was designed to provide investors in foreign countries with certain basic protections and assurances (United States Trade Representative, 2016) such as:

- "Freedom from discrimination: An assurance that Americans doing business abroad will face a level playing field and will not be treated less favorably than local investors or competitors from other countries."

- "Protection against uncompensated seizure of property (e.g., Hunter, 2006): An assurance that property of American investors won't be seized by the government without just compensation" under generally recognized principles of international law relating to expropriation, confiscation, and nationalization.

- "Protection against denial of due process: An assurance that investors will not be denied justice" or due process on the same basis of the nationals of host countries in criminal, civil, or administrative proceedings.

- "Right to transfer capital: An assurance that investors will be able to move capital relating to their investments freely" (relating to "blocking" of currencies (Britchenko, 2018), subject to reasonable procedural and substantive safeguards designed to provide the host government with "flexibility" and the ability to "respond to a financial crises and [to] ensure the integrity and stability of the financial system."

Bradlow (2018) added that the ISDS would also enable private sector parties to bring human rights claims through the dispute-settlement mechanism.

The ISDS provision rallied critics from both the left and right in American politics. Conservative critics argued that the TPP was yet another example of the diminution of U.S. sovereignty (Jones, 2007). Elbel (2015, pp. 53-54) stated: "The TPP would establish an entirely separate parallel system of justice involving special extra-judicial tribunals. These tribunals would adjudicate claims by foreign investors that their economic interests might be harmed by a signatory nation. Thus, a multinational corporation could sue federal, state, and even local officials for impinging on anticipated, unrealized, and imagined future corporate profits." 
Economists Joseph Stiglitz and Adam S. Hersh (2015) criticized the ISDS provisions of the TPP for interfering with the ability of governments to prevent "public harm." They opined that if asbestos been discovered today, governments would have been unable to impose regulations without creating potential grounds for an ISDS suit. Stiglitz further claimed that the TPP would give oil companies the right to sue governments for their efforts to reduce carbon emissions and take actions against global warming (Stiglitz, 2015). Stiglitz (2015) stated: "But under these provisions, corporations can sue the government, including the American government, by the way, so it's all the governments in the TPP can be sued for the loss of profits as a result of the regulations that restrict their ability to emit carbon emissions that lead to global warming."

Another furious critic has been Columbia professor Jeffrey Sachs of the Earth Institute who concluded that the ISDS mechanism vested huge power in investors in multi-national corporation (MNC), and weakened the judicial systems of host countries in favor of multi-national interests. Sachs alleged that the ISDS had already been used by MNCs to weaken regulations that have negative effects on their profits (Sachs, 2015). Dr. Sachs noted that the "drafts on investor rights, the environment, labor and intellectual property make extravagant concessions to powerful corporate interests while leaving important social and environmental commitments vague and generally unenforceable. Globalization is indeed so important for our common good that it's of overriding significance to get it right" (Sachs, 2015).

However, it should be noted that the TPP specifically excluded the tobacco industry from the ISDS process (Bollyky, 2016). The "carve-out" came as a response to concerns raised by several nations over the objections of tobacco producers in the United States about the possibility of a rash of potential cases filed by tobacco manufacturers challenging anti-smoking laws. [It should be noted, as Tienhaara and Gleeson (2015) report, "Corporations based in the United States have been by far the biggest users of ISDS and the rights of US investors have been interpreted broadly in 98 per cent of cases."] An example was the case of Philip Morris v. Uruguay (2010/2016) in which Philip Morris alleged that Uruguay's anti-smoking legislation had devalued its cigarette trademarks and investments in Uruguay (generally, Nightingale, 2016). Philip Morris sued Uruguay for compensation under the bilateral investment treaty between Switzerland and Uruguay (Lin, 2013; Radi, 2018). [In the end, the Court found in favor of Uruguay, forcing Philip Morris to pay the litigation expenses of Uruguay and court costs.]

\section{The Proverbial "BotToM Line"}

For the Obama's administration, the TPP was the center-piece of an Asia-focused strategy to engage both economic and geopolitical interests and in the belief that further liberalizing trade would be a benefit for the U.S. economy. The Obama administration argued that lower tariffs and increased market access would reduce consumer prices, encourage cross-border investment, and boost U.S. exports (McBride, 2018). The administration maintained that the TPP would support many highpaying American jobs and generate an additional $\$ 123.5$ billion a year in income by 2025 , increasing the GDP of the United States by $0.5 \%$ (Lee, 2015).

After President Trump announced that the United States would withdraw from TPP, the remaining eleven countries became known as TPP-11. Without the participation of the United States, the TPP's share of world trade dropped from 38\% to $13.5 \%$. Interestingly, the new TPP-11 agreement (the CPTPP) (Ministry of Foreign Affairs and Trade (New Zealand), 2018) provided for several major changes and included a "walk back" of several of the rules insisted upon by the United States, but which were unpopular among the remaining eleven countries. The main change was in the area of intellectual property protections. The CPTPP removed provisions relating to longer copyright terms, patent extensions, and protections that had been extended to medical technologies like biologics. The Investment chapter was also modified. The remaining eleven countries retained the investor-state dispute settlement (ISDS) mechanism but they modified and further limited its scope. As Patel (2017, p. 302) noted: "Changes to ISDS signal an emerging shift towards further safeguards against ISDS abuses and greater protections for host state sovereignty." Few of the implementation deadlines and labor and environmental rules, however, were changed (McBride, 2018).

\section{CONCLUSIONS AND OBSERVATIONS}

Despite the U.S. exit from the TPP agreement, it appears that the remaining nations are managing the situation well and striving to make it a success. Interestingly, President Trump has shown an interest in returning to the TPP (Swanson, 2018); however, his preference for negotiating bilateral (or perhaps 
trilateral) trade agreements and his movement towards imposing tariffs to ensure a more favorable treatment for United States trade interests may prevent that possibility (Lee, 2018) —at least in the short run.

By rejoining a new TPP, the United States will be a partner with countries that make up nearly $40 \%$ of the global economy (Bradner, 2017). More importantly from a strategic point of view, the United States would be able to stand against China's growing power as its seeks to supplant the United States as the preeminent economic and political power in the Pacific region. China has embarked on an ambitious plan, known as "Made in China 2025," in which China would become not only a manufacturing powerhouse and a high-tech manufacturing powerhouse in "high tech industries like artificial intelligence, robotics and space travel" (Bennett \& Bender, 2018). Clover (2018) reports that China is planning to "achieve 50 percent self-sufficiency by 2020 and 70 percent self-sufficiency in specific industries by 2025."

Council of Foreign Relations member Edward Alden and others have argued that withdrawing from the TPP has reduced Washington's leverage and in fact has "made it harder to deal with China's abuses" (Riley, 2017). Since the American withdrawal from the TPP, China has expressed interest in being a part of a separate trade agreement, the Regional Comprehensive Economic Partnership (RCEP), which would include sixteen Asia-Pacific counties, but which would exclude the United States. Partially, no doubt, in response to the vacuum created by the American withdrawal from the TPP, China has launched the "Belt and Road Initiative" (Lingliang, 2016; Rolland, 2017) first initiated by Chinese President XI Jinping during his visits in Central Asia and Southeast Asia in September and October of 2013, to develop trade and energy infrastructure throughout South and Central Asia (McBride, 2018).

\section{REFERENCES}

[1] Bennett, C. \& Bender, B. (2018). How China acquires the 'crown jewels' of U.S. technology. South China Morning Post (May 22, 2018). Available: https:/www.scmp.com/news/china/diplomacy-defence/ article/ 2147288/how-china-acquires-crown-jewels-us-technology

[2] Berger, S. (2015). Hillary Clinton comes out against TPP, reverses her position. International Business Times (October 7, 2015). Available: https://www.ibtimes.com/hillary-clinton-comes-out-against-tppreverses- her-position-2131697

[3] Bohn, T. \& Brakman, S. (2018). The role of services in globalization. The World Economy (March 26, 2018): 1-18. Available: https://onlinelibrary.wiley.com/doi/full/10.1111/twec.12640

[4] Bollyky, T.J. (2016). TPP tobacco exception proves the new rule in trade. Council on Foreign Relations (February 4, 2016). Available: https://www.cfr.org/expert-brief/tpp-tobacco-exception-proves-new-rule-trade

[5] Bradlow, A.H. (2018). Human rights impact litigation in ISDS: a proposal for enabling private parties to bring human rights claims through investor-state dispute settlement mechanisms, Yale Journal of International Law, 43: 355-390.

[6] Bradner, E. (2017). Trump's TPP withdrawal: 5 things to know. Available: https://www.cnn.com/2017/01/ 23/politics/trump-tpp-things-to-know/index.html

[7] Braga, C.A. (2016). TPP: the new gold standard for intellectual property protection in trade agreements? East West Center (March 24, 2016). Available: https://www.eastwestcenter.org/news-center/east-westwire/tpp-the-new-gold-standard-intellectual-property-protection-in-trade

[8] Britchenko, I. (2018). State regulation of the national currency exchange rate by gold and foreign currency reserve management (Monograph). Tarnobrzeg, Poland: Tarnobrzeg Wydawnictwo Panstowo.

[9] Calmes, J. (2016). What is lost by burying the Trans-Pacific Partnership? New York Times (November 11, 2016). Available: https://www.nytimes.com/2016/11/12/business/economy/donald-trump-trade-tpp-transpacific-partnership.html

[10] Capaldo, J. \& Izurieta, A. (2016a). Income inequality, jobs and wages, TPP, wealth inequality. Tufts University Report. Available: https://popularresistance.org/tufts-univ-report-tpp-means-inequality-lostjobs-lower-wages/

[11] Capaldo, J., \& Izurieta, A. (2016b). Trading down: unemployment, inequality and other risks of the TransPacific Partnership agreement. Global Development and Environment Institute, Working Paper 16(01). Available: http://www.ase.tufts.edu/gdae/Pubs/wp/16-01Capaldo-IzurietaTPP.pdf

[12] Carroll, L. (2015). What Hillary Clinton really said about TPP and the 'gold standard.' Politifact (October 13, 2015). Available: https://www.politifact.com/truth-o-meter/statements/2015/oct/13/hillary-clinton/ what-hillary-clinton-really-said-about-tpp-and-gol/ 
[13] Che-Ahmad, A.B. \& Mustafa, A.S. (2017). Ownership patterns and control of top Malaysian listed companies. SHS Web Conference (17 ${ }^{\text {th }}$ Annual Conference of the Asian Academic Accounting Association). Available: https://www.shs-conferences.org/articles/shsconf/pdf/2017/02/...

[14] Cheng, T-H. (2006). Power, norms, and international intellectual property law. Michigan Journal of International Law, 28: 109-155.

[15] Chow, D.C.K. (2017). Can the United States impose trade sanctions on China for currency manipulation? Washington University Global Studies Law Review, 16: 295-328.

[16] Clover, C. (2018). Chinese courts curb IP theft as US sees bigger threat. Financial Times (May 29, 2018). Available: https://www.ft.com/content/bf59f00c-425e-11e8-97ce-ea0c2bf34a0b

[17] Contractor, F. (2016). Does China manipulate its currency like Donald Trump says? U.S. News \& World Report (June 22, 2016). Available: https://www.usnews.com/news/best-countries/articles/2016-0622/does-china-manipulate-its-currency-like-donald-trump-says

[18] Davison, R. (2015). Debunking the TPP myths. Australian Business Review. Available: https://www. theaustralian.com.au/business/business-spectator/news...

[19] DeFilippo, C., \& Powers, W. (2016). Trans-Pacific Partnership agreement: likely impact on the U.S. economy and on specific industry sectors. Available: https://www.federalregister.gov/documents/2015/ 11/20/2015-29659/trans-pacific-partnership-agreement-likely-impact-on-the-us-economy-and-on-specificindustry-sectors

[20] Durden, T. (2017). US trade deficit in 2016 was the biggest in four years. Daily Mail (February 7, 2017). Available: www.dailymail.co.uk/.../US-2016-trade-deficit-highest-four-years.html

[21] Elbel, Fred. (2015). The sovereignty-busting Trans-Pacific Partnership. The Social Contract, 25(4), 53-59. Available: http://www.cairco.org/highlights/secretive-sovereignty-subverting-trans-pacific-partnership

[22] Elms, D. (2017). The origins and evolution of the Trans-Pacific Partnership (TPP) trade negotiations. Asian Trade Centre Working Paper. Available: https://static1.squarespace.com/static/5393d501e4b06 43446abd228/t/553863b5e4b05d21beba47de/1429758901304/TPP Origins Working Paper.pdf.

[23] Fergusson, I.F., McMinimy, M.A., \& Williams, B.R. (2016). The Trans-Pacific Partnership (TPP) - in brief. Congressional Research Service. Available: https://fas.org/sgp/crs/row/R44278.pdf

[24] Gao, H.S. (2010). The Trans-Pacific Strategic Economic Partnership Agreement: a critical analysis. Legal Issues of Economic Integration, 37: 221-240.

[25] George, M. (2013). Does cross-border regulation really influence cross-border trade? Evidence from the services trade restriction index. HAL Archives (University of Paris). Available: https://dumas.ccsd. cnrs.fr/dumas-00909960

[26] Gerwin, E. (2015). The trans-pacific partnership and small business: boosting exports and inclusive growth. Progressive Policy Institute (November 2015). Available: www.progressivepolicy.org/wp-content/ uploads/2015/11/2015.11...

[27] Granville, K. (2016). The Trans-Pacific Partnership trade accord explained. New York Times (International Business) (July 26, 2016). Available: https://www.nytimes.com/2016/07/27/business/ international/the-trans-pacific-partnership-trade-accord-explained.html

[28] Green, M. \& Goodman, M. (2015). After TPP: the geopolitics of Asia and the Pacific. The Washington Quarterly, 38(4): 19-34. Available: http://www.tandfonline.com/doi/abs/10.1080/0163660X.2015. 1125827

[29] Guisinger, A. (2017). American opinion on trade: preferences without politics. New York: Oxford University Press.

[30] Harvey, B. (2017). Evaluating financial integration and cooperation in the ASEAN. Michigan Business and Entrepreneurial Law Review, 7: 119-158.

[31] Hunter, R.J. (2006). Property risks in international business. Currents: International Trade Law Journal, XV (1): 23-42.

[32] Hunter, R.J. \& Lozada, H. (2010) A primer on issues in international trade. International Research Journal of Finance and Economics, 47: 99-110.

[33] International Trade Commission (2016). Trans-Pacific Partnership agreement: likely impact on the U.S. economy and on specific industry sectors. Available: https://www.federalregister.gov/documents/2015/ 11/20/2015-29659/trans-pacific-partnership-agreement-likely-impact-on-the-us-economy-and-on-specificindustry-sectors

[34] Jegarajah, S., Dame, C., \& Shaffer, L. (2017). TPP nations agree to pursue trade deal without US. CNBC: Politics (May 21, 2017). Available: https://www.cnbc.com/2017/05/20/tpp-nations-agree-to-pursue-tradedeal-without-us.html 
[35] Jones, C.W. (2007). Trade pacts threaten sovereignty. Available: https://boilermakers,org/resources/ commentary/V403.

[36] Kaul, D. (2017). Eliminating trade barriers through preferential trade agreements: perspectives from South Asia. Tulane Journal of International and Comparative Law, 25: 355-402.

[37] Klein, M.W. (2015). What you may not know about China and currency manipulation. Brookings (May 22, 2015). Available: https://www.brookings.edu/opinions/what-you-may-not-know-about-china-andcurrency-manipulation/

[38] Labonte, R., Schram, A., \& Ruckert, A. (2016). The Trans-Pacific Partnership: is it everything we feared for health? International Journal of Policy Management, 5(8): 487-496.

[39] Lazo, R.P. \& Fiedler, S.G. (2017). A requiem for the Trans-Pacific Partnership: something new, something old and something borrowed? Melbourne Journal of International Law, 18: 298-348.

[40] Lee, D. (2015.) The Trans-Pacific Partnership trade pact: what's in it for the U.S.? Los Angeles Times (October 5, 2015). Available: http://www.latimes.com/nation/la-na-tpp-trade-qa-20150513-story.html

[41] Lin, T. (2013). Preventing tobacco companies' interference with tobacco control through investor-state dispute settlement under the TPP. Asian Journal of WTO and International Health and Policy, 8(2): 565582.

[42] Lingliang, Z. (2016). Conceptual analysis of China's belt and road initiative: a road towards a regional community of common destiny. Chinese Journal of International Law, 15(3), 517-541.

[43] Martin, P. (2015). Secret agreement bad for heath. The Lamp, 72(11): 32-33. Available: http://www. nswnma.asn.au/secret-agreement-bad-for-health/

[44] McBride, J. (2018). What is the Trans-Pacific Partnership (TPP)? Council on Foreign Relations (May 15, 2018). Available: https://www.cfr.org/backgrounder/what-trans-pacific-partnership-tpp

[45] Ming, C. (2018). Global trade just had a 'one step forward, one step back' day. CNBC World Economy/Daily Times (March 9, 2018). Available: https://dailytimes.com.pk/213694/global-trade-just-had -a-one-step-forward-one-step-back-day/

[46] Mitchell, A.D. \& Mishra, N. (2018). Data at the Docks: Modernizing International Trade Law for the Digital Economy. Vanderbilt Journal of Entertainment and Technology Law, 20: 1073-1134.

[47] Mui, Y.Q. (2017). President Trump signs order to withdraw from trans-pacific partnership. Washington Post (January 23, 2017). Available: https://www.washingtonpost.com/news/wonk/wp/2017/01/23/ president-trump-signs-order-to-withdraw-from-trans-pacific-partnership.html

[48] Naughton, B., Kroeber, A.P., De Jonquires, G., \& Wenster, G. (2015). What will the TPP mean for China? Foreign Affairs (October 7, 2015): Available: https://international.gc.ca/trade-commerce/tradeagreements-accords-commerciaux/agr-acc/cptpp-ptpgp/index.aspx?lang=eng

[49] Nightengale, A. (2016). The significance of Uruguay's win over Philip Morris International. Intellectual Property Watch (July 21, 2016). Available: http://www.ip-watch.org/2016/07/21/the-significance-ofuruguays-win-over-philip-morris-international/

[50] Otero, H. \& Garcia-Bolivar, O. (2011). International arbitration between foreign investors and host states. Available: http://www.nyulawglobal.org/globalex/International_Arbitration_Foreign_Investors_Host_States1.html

[51] Patel, N. (2017). An emerging trend in international trade: a shift to safeguard against ISDS abuses and protect host-state sovereignty. Minnesota Journal of International Law, 26(1): 273-302.

[52] Perlez, J. (2015). U.S. allies see trans-pacific partnership as a check on China. New York Times (October 7, 2015). Available: https://cn.nytimes.com/asia-pacific/20151008/c08tradepolitics/en-us/

[53] Peterson, J. (2017). An overview of customs reforms to facilitate trade. Journal of International Commerce and Economics, 2017: 1-30.

[54] Pezard, A. (1995). The golden share of privatized companies. Brooklyn Journal of International Law, 21: 85-95.

[55] Philip Morris v. Uruguay (2010/2016). ICSID [International Center for the Settlement of Investment Disputes] Case No. ARB/10/7. Available: http://isdsblog.com/2016/08/25/philip-morris-v-uruguay/

[56] Provost, C. \& Kennard, M. (2015). The obscure legal system that lets corporations sue countries. The Guardian (June 10, 2015). Available: www.dailymail.co.uk/.../US-2016-trade-deficit-highest-fouryears.html

[57] Quick, R. (2015). Why TPP should have an investment chapter including ISDS. Journal of World Trade, 2: 199-209.

[58] Radi, Y. (2018). Philip Morris v. Uruguay: regulatory measures in international investment law: to be or not to be compensated? Foreign Investment Law Journal, 33(1): 74-80.

[59] Riley, C. (2017). Trump's decision to kill TPP leaves door open for China. CNN Money. Available: https://money.cnn.com/2017/01/23/news/economy/tpp-trump-china/index.html 
[60] Rolland, N. (2017). China's Eurasian century? Political and strategic implications of the belt and road initiative. Seattle, Washington: National Bureau of Asian Research.

[61] Sachs, J. (2015). Why the TPP is too flawed for a 'yes' vote in Congress. Boston Globe (December 6, 2017). Available: https://www.bostonglobe.com/opinion/2015/11/08/jeffrey-sachs-tpp...

[62] Stiglitz, J. (2015). Under TPP, polluters could sue U.S. for setting carbon emissions limits. Democracy Now (October 27, 2015). Available: https://www.democracynow.org/2015/10/27/joseph_stiglitz_under_ tpp_polluters_could

[63] Stiglitz, J. \& Hersh, A.S. (2015). The Trans-Pacific Partnership charade: TPP isn't about "free trade" at all. Market Watch (October 2, 2015). Available: https://www.marketwatch.com/story/the-trans-pacificpartnership-charade-tpp-isn't about-free-trade-at-all-2015-10-05

[64] Sumner, D.A., Smith, V.H., \& Rosson, C.P. (2001). Tariff and non-tariff barriers to trade. Institute for Agriculture and Trade Policy. Available: http://www.iatp/documents/Tariff_and_Non-tariff_Barriers_to_ Trade.htm

[65] Swanson, A. (2018). Trump proposes rejoining Trans-Pacific Partnership. New York Times (April 12, 2018). Available: https://www.nytimes.com/2018/04/12/us/politics/trump-trans-pacific-partnership.html

[66] Taylor, A. (2018, April 13). A timeline of Trump's complicated relationship with the TPP. Available: https://www.washingtonpost.com/news/worldviews/wp/2018/04/13/a-timeline-of-trumps-complicatedrelationship-with-the-tpp/?utm_term $=.84456530 \mathrm{~b} 3 \mathrm{e} 0$

[67] Tienhaara, K. \& Gleeson, D. (2015). 'Modified version' of investor clause no fix in TPP. The Drum (July 31, 2015). Available: https://www.latrobe.edu.au/news/articles/2015/opinion/investor-clause-modificationno-tpp-fix

[68] Tupy, M.L. (2018). Trump should revisit the TPP to rein in China. Human Progress (June 26, 2018). Available: https://humanprogress.org/article.php?p=1371

[69] WikiLeaks. (2013). WikiLeaks secret Trans-Pacific Partnership agreement (TPP) - investment chapter (March 25, 2015). Available: https://wikileaks.org./tpp-investment

[70] Wong, J. (2017). Data protection for biologics - should the exclusivity period be increased to 12 years? Intellectual Property Forum: Journal of the Intellectual and Industrial Property Society of Australia and New Zealand, 108: 58-70. Available: https://papers.ssrn.com/sol3/papers.cfm?abstract_id=2831262

\section{DOCUMENTS}

[1] Comprehensive and Progressive Agreement for Trans-Partnership (TPP-11) (March 8, 2018). Available: https://dfat.gov.au/TRADE/AGREEMENTS/NOT-YET-IN-FORCE/TPP-11/Pages/trans-pacificpartnership-agreement-tpp.aspx

[2] Ministry of Foreign Affairs \& Trade (New Zealand). (2005). Trans-Pacific Strategic Economic Partnership (P-4 Agreement). Available: https://web.archive.org/2013021015141458

[3] Ministry of Foreign Affairs \& Trade (New Zealand). (2018). Comprehensive and Progressive Agreement for Trans-Pacific Partnership (CPTPP) (TPP-11). Available: https://international.gc.ca/trade-commerce/ trade-agreements-accords-commerciaux/agr-acc/cptpp-ptpgp/index.aspx?lang=eng

[4] Presidential Memorandum Regarding Withdrawal of the United States from the Trans-Pacific Partnership Negotiations and Agreement (January 23, 2017). Available: https://www.whitehouse.gov/presidentialactions/presidential-memorandum-regarding-withdrawal-united-states-trans-pacific-partnershipnegotiations-agreement/

[5] United States Trade Representative. (2016). Trans-Pacific Partnership (Full Text). Available: https://ustr. gov/trade-agreements/free-trade-agreements/trans-pacific-partnership/tpp-full-text

\section{APPENDIX I}

\section{Presidential Memorandum Regarding Withdrawal of the United States from the Trans-Pacific Partnership Negotiations and Agreement}

Issued on: January 23, 2017

\section{MEMORANDUM FOR THE UNITED STATES TRADE REPRESENTATIVE}

SUBJECT: Withdrawal of the United States from the Trans-Pacific Partnership Negotiations and Agreement

It is the policy of my Administration to represent the American people and their financial well-being in all negotiations, particularly the American worker, and to create fair and economically beneficial trade deals that serve their interests. Additionally, in order to ensure these outcomes, it is the intention 
of my Administration to deal directly with individual countries on a one-on-one (or bilateral) basis in negotiating future trade deals. Trade with other nations is, and always will be, of paramount importance to my Administration and to me, as President of the United States.

Based on these principles, and by the authority vested in me as President by the Constitution and the laws of the United States of America, I hereby direct you to withdraw the United States as a signatory to the Trans-Pacific Partnership (TPP), to permanently withdraw the United States from TPP negotiations, and to begin pursuing, wherever possible, bilateral trade negotiations to promote American industry, protect American workers, and raise American wages.

You are directed to provide written notification to the Parties and to the Depository of the TPP, as appropriate, that the United States withdraws as a signatory of the TPP and withdraws from the TPP negotiating process.

You are authorized and directed to publish this memorandum in the Federal Register.

\section{DONALD J. TRUMP}

\section{APPENDIX II}

TPP Final Table of Contents

Chapters

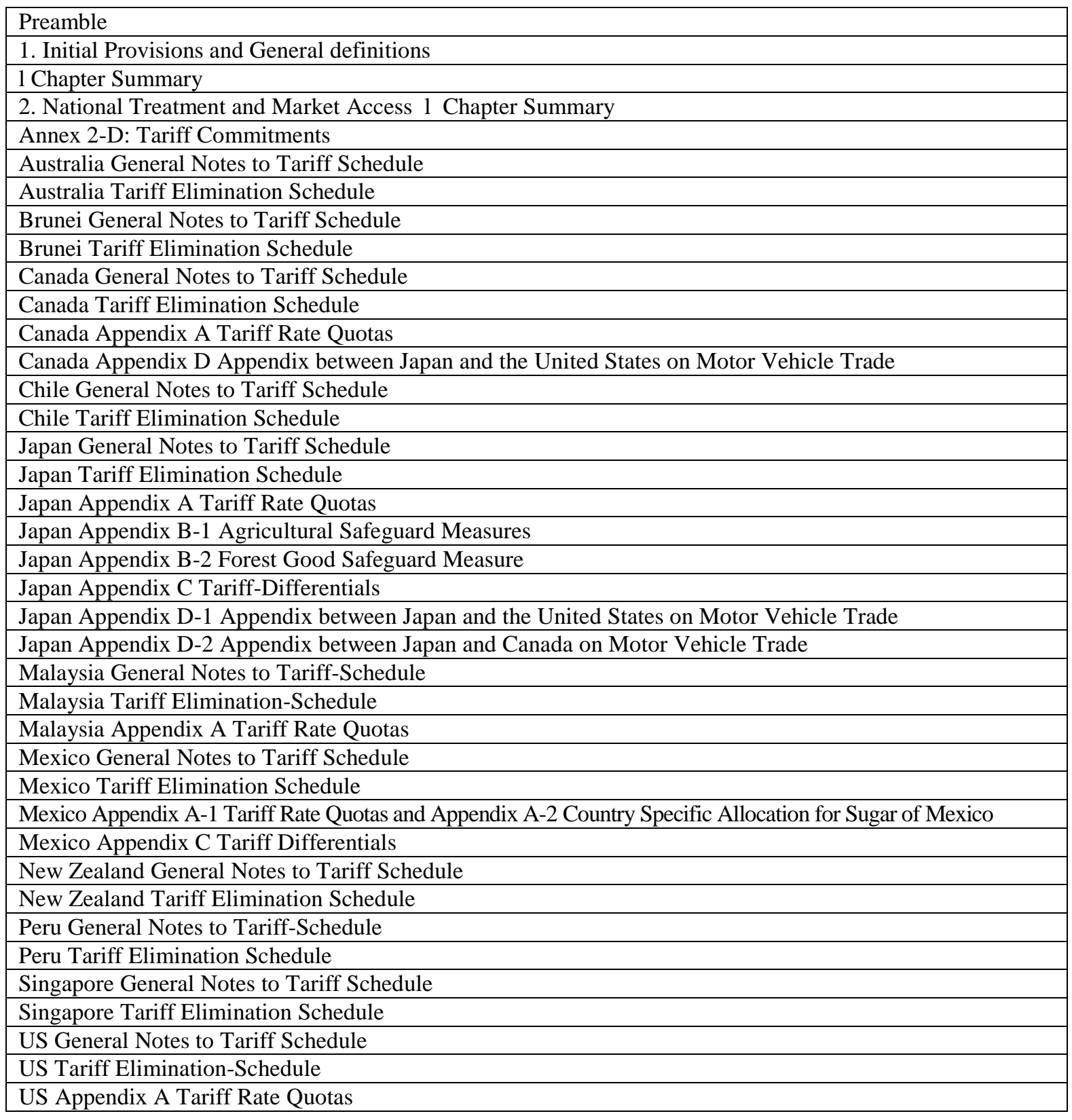


US Appendix B Agricultural Safeguard Measures

US Appendix C Tariff Differentials

US Appendix D Appendix between Japan and the United States on Motor Vehicle Trade

US Appendix E Earned Import Allowance Program

Viet-Nam General Notes to Tariff Schedule

Viet-Nam Tariff Elimination Schedule

Viet-Nam Appendix A Tariff Rate Quotas

3. Rules of Origin and Origin Procedures 1 Chapter Summary

Annex 3-D: Product Specific Rules

Annex 3-D: Appendix 1-Automotive

4. Textiles and Apparel 1 Chapter Summary

Annex 4-A: Textiles Product Specific Rule

Annex 4-A Appendix 1: Short Supply List

5. Customs Administration and Trade Facilitation 1 Chapter Summary

6. Trade Remedies 1 Chapter Summary

7. Sanitary and Phytosanitary Measures 1 Chapter Summary

8. Technical Barriers to Trade 1 Chapter Summary

9. Investment 1 Chapter Summary

10. Cross Border Trade in Services 1 Chapter Summary

11. Financial Services 1 Chapter Summary

12. Temporary Entry for Business Persons 1 Chapter Summary

Annex 12-A: Temporary Entry for Business Persons

Australia

Brunei

Canada

Chile

Japan

Malaysia

Mexico

New Zealand

Peru

Singapore

Viet Nam

13. Telecommunications 1 Chapter Summary

14. Electronic Commerce 1 Chapter Summary

15. Government Procurement 1 Chapter Summary

Annex 15-A: Government Procurement

Australia

Brunei

Canada

Chile

Japan

Malaysia

Mexico

New Zealand

Peru

Singapore

United States

Viet Nam

16. Competition 1 Chapter Summary

17. State-Owned Enterprises 1 Chapter Summary

18. Intellectual Property 1 Chapter Summary

19. Labour 1 Chapter Summary

US-BN Labour Consistency Plan

US- MY Labour Consistency Plan

US-VN Plan for Enhancement of Trade and Labour Relations

20. Environment 1 Chapter Summary

21. Cooperation and Capacity Building 1 Chapter Summary

22. Competitiveness and Business Facilitation 1 Chapter Summary

23. Development 1 Chapter Summary 


\begin{tabular}{|l|}
\hline 24. Small and Medium-Sized Enterprises 1 Chapter Summary \\
\hline 25. Regulatory Coherence 1 Chapter Summary \\
\hline 26. Transparency and Anti-Corruption 1 Chapter Summary \\
\hline 27. Administrative and Institutional Provisions 1 Chapter Summary \\
\hline 28. Dispute Settlement 1 Chapter Summary \\
\hline 29. Exceptions 1 Chapter Summary \\
\hline 30. Final Provisions 1 Chapter Summary \\
\hline (United States Trade Representative, 2016). \\
\hline
\end{tabular}

\section{AUTHOR'S BIOGRAPHY}

Richard J. Hunter, Jr. is Professor of Legal Studies and Economics at Seton Hall University.

Subhasree Nepali is a candidate for the MBA degree in the Stillman School of Business, Seton Hall University.

Citation: Roja Subhasree Neppalli, Richard J. Hunter, Jr. "To TPP or Not to TPP: That is Still the Question" International Journal of Managerial Studies and Research (IJMSR), vol 6, no. 11, 2018, pp. 76-87. doi: http:// dx.doi.org/10.20431/2349-0349.0611009.

Copyright: (c) 2018 Authors. This is an open-access article distributed under the terms of the Creative Commons Attribution License, which permits unrestricted use, distribution, and reproduction in any medium, provided the original author and source are credited. 